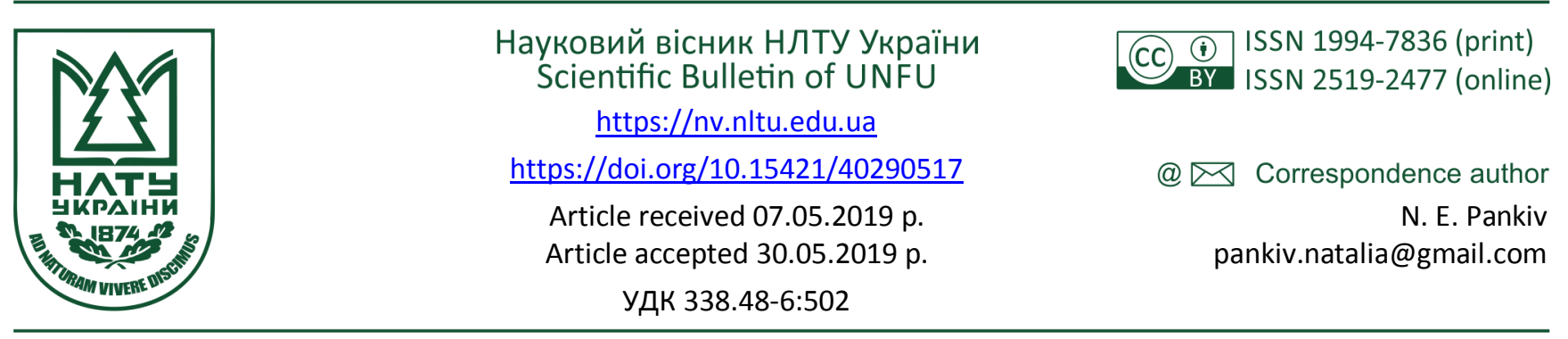

Н. Є. Паньків

Національний університет "Львівська політехніка", м. Львів, Україна

\title{
ПРИРОДООХОРОННІ ТЕРИТОРІЇ ЯК БАЗА РОЗВИТКУ ЕКОЛОГІЧНОГО ТУРИЗМУ У ЛЬВІВСЬКІЙ ОБЛАСТІ НА ПРИКЛАДІ НАЦІОНАЛЬНОГО ПРИРОДНОГО ПАРКУ "СКОЛІВСЬКІ БЕСКИДИ"
}

\begin{abstract}
Проаналізовано наявні об'єкти природно-заповідного фонду Львівської області, які мають важливе рекреаційне туристичне значення. Виявлено, що найбільше значення для рекреаційно-туристичної сфери мають національні природні парки, в яких активно розвивається екологічний туризм. Проаналізовано особливості розвитку екологічного туризму у Національних природних парках та встановлено, що найпоширенішим видом екологічного туризму у природно-заповідних зонах $є$ прогулянки екологічними стежками. Розглянуто рекреаційно-туристичні ресурси Національного природного парку "Сколівські Бескиди", шляхи їх збереження та раціонального використання. Зокрема, еколого-пізнавальні стежки та маршрути: "м. Сколе - г. Парашка - с. Майдан"; "Бучина"; "Лопата"; "Водоспад"; "Нижнє Синьовидне - Труханів - гора Ключ - Сколе" та велосипедний маршрут "Сколе - Ключ - Скелі Довбуша - Болехів - Стрий". Встановлено, що перспективними для рекреаційного використання є долина р. Велика річка, фортеця "Тустань" (Підгородцівське лісництво), долина р. Кам'янки (Дубинське лісництво), урочища Павлів Потік, Зелем'янка (Сколівське лісництво), м. Сколе, урочище Панасівка (Коростівське лісництво). Висвітлено проблеми та перспективи використання рекреаційно-туристичних ресурсів Сколівщини для екотуризму.
\end{abstract}

Ключові слова: рекреаційно-туристичні ресурси; природно-заповідний фонд; Національні природні парки; НПП "Сколівські Бескиди"; екологічний туризм.

Вступ. Важливе рекреаційне туристичне значення у Львівській обл. мають заповідні території, хоч їх основне призначення - збереження типових для цієї зони об'єктів, а також збереження та відновлення цінних та унікальних природних комплексів чи їх важливих складових елементів (Pankiv, 2017).

Завдяки багаторічній праці фахівців у сфері заповідної справи на території Львівської області, на 01.01.2018 р. функціонує 358 територій та об'єктів природно-заповідного фонду, загальною площею 158,1 тис. га, що становить 7,2 \% від площі території області. 10 об'єктів природно-заповідного фонду є природоохоронними установами зі спеціальними адміністраціями, а саме: природний заповідник "Розточчя", національний природний парк "Сколівські Бескиди", Яворівський національний природний парк, національний природний парк "Північне Поділля", ботанічний сад Львівського національного університету ім. Івана Франка, ботанічний сад Національного лісотехнічного університету України, регіональні ландшафтні парки "Знесіння", "Равське Розточчя", "Верхньодністровські Бескиди", "Надсянський" та "Стільське Горбогір'я". Найбільшу площу в структурі природно-заповідного фонду області займають національні природні парки - Сколівські Бескиди, Яворівський і Північне Поділля - загальна площа 58,3 тис. га, або 39 \% від загальної площі територій та об'єктів ПЗФ, регіональні ландшафтні парки -
47379,0 га $\quad(35,74 \%$ площі 30429,3 га (22,95 \% площі ПЗФ).

Разом $з$ тим, варто зауважити, що майже 65 \% всієї площі ПЗФ області розташовано на території лісового фонду, а отже, у природних комплексах, що перебувають під особливою охороною держави. Переважають лісові формації та угруповання і значно нижчий відсоток лучних, лучно-степових, лучно-болотних, водно-болотних формацій.

3 них у підпорядкуванні: Мінприроди України - 1 (Яворівський НПП); Держкомлісгоспу України - 1 (НПП "Сколівські Бескиди"); Міносвіти України - 4 (природний заповідник "Розточчя", 3 ботанічні сади); Органів місцевого самоврядування - 4 (РЛП "Знесіння"' РЛП "Верхньодністровські Бескиди", "Надсянський", "Равське Розточчя") (LODA, 2019).

Метою дослідження є аналіз наявних рекреаційнотуристичних ресурсів Сколівського р-ну Львівщини, сприятливих для розвитку екологічного туризму на прикладі Національного природного парку "Сколівські Бескиди".

Матеріали і методи дослідження. У процесі дослідження застосовували аналітичний, порівняльно-географічний методи, а також методи узагальнення та систематизації.

Охорона об'єктів природно-заповідного фонду забезпечується встановленням заповідного режиму, орга-

\section{Інформація про авторів:}

Паньків Наталія Євгенівна, канд. біол. наук, доцент, кафедра туризму. Email: pankiv.natalia@gmail.com

Цитування за ДСту: Паньків Н. Є. Природоохоронні території як база розвитку екологічного туризму у Львівській області на прикладі національного природного парку "Сколівські Бескиди". Науковий вісник НЛтУ України. 2019 , т. 29, № 5. С. 88-92.

Citation APA: Pankiv, N. E. (2019). Protected areas as a base for the development of ecological tourism in Lviv region on the example of Skolevsky Beskydy national nature park. Scientific Bulletin of UNFU, 29(5), 88-92. https://doi.org/10.15421/40290517 
нізацією систематичних спостережень i досліджень, здійсненням державного i громадського контролю, встановленням підвищеної відповідальності тощо. До того ж ці об'єкти можуть використовуватися тільки для природоохоронних, науково-дослідних, оздоровчих та освітньо-виховних цілей. Управління у сфері охорони природно-заповідного фонду здійснює Міністерство охорони навколишнього природного середовища України та його органи на місцях. Безпосереднє управління більшістю об'єктів природно-заповідного фонду здійснюється спеціальними адміністраціями, до складу яких входять відповідні наукові підрозділи, служби охорони, господарського та іншого обслуговування. Згідно зі Законом право участі в управлінні вказаними об'єктами належить і відповідним об'єднанням громадян.

Треба зазначити, що різні види природоохоронних територій характеризуються різними ступенями заповідності. Так, для рекреаційних потреб заповідники не використовуються. Найбільше значення для рекреаційно-туристичної сфери мають національні природні парки (рекреаційні зони), парки-пам'ятки садово-паркового мистецтва, зоологічні сади, пам'ятки природи.

У національних природних парках (НПП) України активно розвивається екологічний туризм, який грунтується на таких концептуальних засадах: мінімізація негативною впливу туристів на природне середовище та його компоненти; гармонійне поєднання людини, природного середовища та рекреаційної інфраструктури; відвідування рекреаційних природно-заповідних територій та об'єктів; науково-пізнавальне освоєння природного (біотичного, ландшафтного, пейзажного) різноманіття і гуманістичного потенціалу рекреаційних територій; соціальна сумісність (злагода) 3 місцевою мораллю, звичаями і традиціями місцевого населення, територіальними громадами та органами місцевого самоврядування; економічні вигоди і переваги в регіональному розвитку природних територій; гарантія довготривалого збереження природних і культурних ресурсів рекреаційних територій (Vorobiova \& Kharichkov, 2009).

Екологічний туризм - вид туризму, що передбачає відвідування відносно незмінених природних територій 3 пізнавальною метою, має мінімальний вплив на довкілля, сприяє екологічному вихованню й освіті туристів, а також стійкому соціальному, економічному та екологічному розвитку регіонів. У найбільш загальному розумінні екологічний туризм $\epsilon$ формою активного відпочинку з екологічно значущим наповненням - особливий інтегруючий напрямок рекреаційної діяльності людей, що будують свої взаємини з природою та іншими людьми на основі взаємної вигоди, взаємоповаги та взаєморозуміння. Туристи отримують від такого спілкування 3 природою певний фізичний, психологічний, інтелектуальний та емоційний запас міцності та здоров'я, а природа при цьому зазнає мінімальних оборотних впливів і втрат, місцеві мешканці отримують соціальні та економічні стимули до збереження природи та традиційного природокористування. Найпоширенішим видом екологічного туризму у природно-заповідних зонах є прогулянки екологічними стежками (Ekolohichnyi turyzm, 2019).

Результати дослідження. Проаналізовано рекреаційно-туристичні ресурси Сколівщини як базу розвит- ку екологічного туризму на прикладі Національного природного парку "Сколівські Бескиди".

"Сколівські Бескиди" - національний природний парк в Українських Карпатах. Розташований у південній частині Львівської обл., в межах Сколівського і (частково) Турківського та Дрогобицького районів. Парк охоплює частини басейнів річок Стрий та Опір і займає площу 35684 га, з яких 24702 га передано парку в постійне користування. Національний природний парк "Сколівські Бескиди" створено згідно з Указом Президента України від 11 лютого 1999 р. № 157/99 на території Дрогобицького, Сколівського і Турківського p-нів Львівської обл. на загальній площі 35684 га. НПП "Сколівські Бескиди" створено з метою збереження, відтворення та раціонального використання природних ландшафтів, що мають важливе природоохоронне, естетичне, наукове, освітнє, рекреаційне та оздоровче значення (Ukaz Prezydenta Ukrainy, 1999).

Парк $\epsilon$ резерватом майже незайманої природи 3 мальовничими краєвидами західної частини Українських Карпат. Він охоплює північні макросхили Бескид на висоті 600-1200 м 3 віковими чистими буковими лісами природного походження та еталонними смерековими і ялицевими лісами. На території парку є понад 30 джерел мінеральної води, зокрема типу Нафтуся. Поряд з Карпатським та Шацьким НПП, Сколівські Бескиди $є$ одним 3 найбільш залучених до рекреаційної сфери, оскільки поблизу функціонує близько 50 санаторіїв, пансіонатів, баз відпочинку та туристичних кемпінгів.

Для забезпечення охорони, відтворення та рекреаційного використання природних комплексів і об'єктів НПП "Сколівські Бескиди" його територію поділено на такі функціональні зони: заповідна зона; зона регульованої рекреації; зона стаціонарної рекреації; господарська зона (Kadnichanska, 2008).

Заповідна зона призначена для охорони та відновлення найцінніших природних комплексів парку; на ii території заборонено будь-яку господарську та іншу діяльність, що суперечить цільовому призначенню, порушує природний розвиток процесів та явищ, або створює загрозу шкідливого впливу на її природні комплекси й об'єкти.

Зона регульованої рекреації призначена для короткострокового відпочинку та оздоровлення населення. У ній дозволено: проведення санітарних рубок і заходів, пов'язаних із збереженням, відтворенням і ефективним рекреаційним використанням природних комплексів та об'єктів, згідно з Проектом організації території парку; регульований збір грибів, ягід, плодів дикорослих плодових рослин із дотриманням природоохоронного та лісового законодавства; обладнання туристських та еколого-пізнавальних стежок, організація природоохоронної пропаганди, короткотривалі туристські екскурсії й відпочинок населення, збір наукової інформації; регулювання чисельності диких тварин до оптимальної, шляхом відлову 3 наступним переселенням та селекційного відстрілу, спортивне полювання у межах, визначених і закріплених мисливських угідь, з дозволу Мiнекобезпеки України; використання природних ресурсів для задоволення потреб працівників НПП "Сколівські Бескиди" та громадян, які постійно проживають на його території, у сінокосах, випасах, городах і паливі, відповідно до встановлених нормативів. 
Зона стаціонарної рекреації призначена для розміщення готелів, мотелів, кемпінгів та інших об'єктів обслуговування відвідувачів Національного парку. Рекреаційну діяльність на території НПП "Сколівські Бескиди" провадять спеціальні підрозділи, а також інші підприємства, організації на підставі угод з адміністрацією парку.

У межах господарської зони провадиться традиційна господарська діяльність, спрямована на виконання поставлених перед парком завдань, знаходяться населені пункти, об'єкти комунального призначення парку, а також землі інших землевласників і землекористувачів, внесені до складу парку, на яких господарська діяльність провадиться 3 дотриманням загальних вимог до охорони навколишнього природного середовища (PZF, 1999). На територіях регульованої, стаціонарної рекреації та господарської зон заборонено будь-яку діяльність, яка призводить або може призвести до погіршення стану навколишнього природного середовища та зниження рекреаційної цінності території парку.

Перспективними для рекреаційного використання $€$ долина р. Велика річка, фортеця "Тустань" (Підгородцівське лісництво), долина р. Кам'янки (Дубинське лісництво), урочища Павлів Потік, Зелем'янка (Сколівське лісництво), м. Сколе, урочище Панасівка (Коростівське лісництво). НПП "Сколівські Бескиди" має можливості для розвитку тут гірськолижного спорту на міжнародному рівні. Через територію парку проходять автомобільна і залізнична транспортні артерії міжнародного значення, що робить його економічно перспективним, особливо для іноземних рекреантів і туристів. Густа річкова мережа, яку утворюють притоки річок Стрий та Опір, робить цю територію особливо привабливою для літнього туризму, а довгі пологі гірські схили сприяють розвитку гірськолижного спорту. До послуг відвідувачів парку мисливські будиночки, розташовані у Завадківському, Майданському, Сколівському та Підгородцівському лісництвах (Kadnichanska, 2008).

Національний природний парк "Сколівські Бескиди" славиться своїми унікальними ландшафтами, бурхливими водоспадами, кришталево-чистими річками і потоками, мінеральними джерелами, багатою і унікальною флорою і фауною, численними історичними пам'ятками.

Щоб задовольнити потреби відвідувачів та зменшити рекреаційне навантаження на природу, на території парку облаштовано такі рекреаційні зони: "Павлів потік" (Сколівське лісництво); "Джершин" (Сколівське лісництво); "Водоспад на річці Кам'янка" (Сколівське лісництво); "Манмансталь" (Майданське лісництво); "Явори" (Підгородцівське лісництво); "Могила касира" (Бутивлянське лісництво); "Альтана" (Бутивлянське лісництво); "Туристичний притулок Дубина" (Сколівське лісництво); "Еколого-пізнавальний рекреаційний майданчик в ур. Тустань" (Підгородцівське лісництво) (Skolivski Beskydy, 2019).

На території НПП "Сколівські Бескиди" діють різноманітні еколого-пізнавальні стежки та маршрути, одним iз найцікавіших є маршрут "м. Сколе - 2. Параш$\kappa a-c$. Майдан" протяжністю 28 км, цікавий в усі пори року. Навесні можна спостерігати пробудження природи на різних висотах н.р.м. Упродовж літа на високогірних луках буяє різнотрав'я. Восени яскраві шати бука та берези відтіняють темно-зелену хвою ялиць та смерек. Багатство рослинного світу, розмаїття фарб гірських квітів приносять насолоду і знімають втому. Вабить сюди неповторна краса природи, чисте, напоєне ароматом хвої і різноманітних трав, повітря. Хто хоч раз побував тут, ніколи не забуде чудових краєвидів, які відкриваються з гори Парашки. Цікавий цей маршрут ще й тим, що під час його проходження туристи мають змогу побачити природні зміни, зумовлені висотною зональністю (маршрут починається на висоті 440 м н.р.м., а найбільша точка маршруту - гора Парашка має 1268 м н.р.м.). Піднятися на цю найвищу вершину національного природного парку можна різними стежками, проте найзручнішими вважають виходи з міста Сколе та 3 села Коростів.

На території Сколівського лісництва (квартали 4 та 7) по долині Павлового потоку проходить траса екологічно-пізнавальної стежки "Бучина" протяжністю 1,4 км, призначена для короткотривалого відпочинку та може бути використана для проведення "уроків природи" для учнів шкіл району. Стежка починається біля входу до зони відпочинку "Павлів потік" на березі ставу і проходить поряд із двома туристичними базами: "Гуцулка" та "Пролісок", що робить їі привабливою для відпочинку. Початок стежки - на березі ставу, де силами національного природного парку влаштована рекреаційна ділянка обладнана дерев'яними лавками, місцями для розведення вогнищ, мангалами. Поряд із місцем відпочинку розташована криничка "Оксана", де завжди, навіть у дуже гарячу пору, витікає чиста холодна вода.

Еколого-пізнавальна стежка "Лопата" (12 км) - одноденний маршрут середньої складності, загальнодоступний. Протяжність маршруту: 12 км, 750 м вгору і 600 м вниз. Гора Лопата (1210,9 м) - найдоступніша від м. Сколе вершина хребта Зелем'янка. Маршрут починається у м. Сколе. Підйом на вершину г. Лопата триває близько 3-4 год і проходить в основному буковим лісом, частково - мальовничими галявинами і полонинками, з яких відкриваються широкі краєвиди навколишніх гір. Наприкінці літа і восени тут багато ягід та грибів. 3 вершини відкриваються краєвиди на хребет Зелем'янка та інші вершини Сколівських Бескидів.

Еколого-пізнавальна стежка "Долиною річки Кам'янка" (4 км), правої притоки річки Опір - один із найцікавіших об'єктів території національного природного парку "Сколівські Бескиди". Чисте гірське повітря, ліси, що рано навесні вкриті зеленим серпанком молодого листя, крізь який просвічуються гілки дерев; пахощі гірських трав влітку; палітра осінніх барв; рідкісні рослинні угруповання роблять похід еколого-пізнавальною стежкою "Долиною річки Кам'янки" надзвичайно інформативним і незабутнім.

Еколого-пізнавальна стежка "Водоспад" прокладена між двома зонами відпочинку, які найчастіше відвідуються на території НПП "Сколівські Бескиди". Стежка промаркована жовтою лінією на білому фоні. Маршрут проходить у північно-західному напрямку паралельно річці Опір. Початок маршруту із урочища "Павлів потік", яке знаходиться недалеко від залізничного вокзалу м. Сколе. 3 вокзалу дорогою переходимо міст через ріку Опір. Тут можна помилуватися величністю цієї гірської ріки.

Історико-пізнавальний маршрут "Нижне Синьовидне - Труханів - гора Ключ - Сколе" (20 км) розроблено як для досвідчених туристів, так і для початківців. Він може бути як одноденний, так і дводенний. Для новач- 
ків рекомендується дводенний похід. Маршрут не дуже складний. Складність для одноденного походу $\epsilon$ середньою, а для двохденного - легкою. Мета маршруту - гора Ключ. Тут на цій горі у 1914 р. відбулися бої між підрозділами Українських Січових Стрільців та російською армією. Тут же на горі розташована могила Січових Стрільців.

Марирут "Верхнє Синьовидне - Корчин - водоспад Гуркало - гора Парашка - Сколе" бере свій початок 3 села Верхнє Синьовидне. Прибувши до села Корчин є можливість побачити гору Парашку та їі хребет. Далі Водоспад Гуркало, який має дуже гарний вигляд і чарує око мандрівника. Потоки води спадають у невеличке озеро, де влітку можна сміливо скупатися, хоча вода в озерці доволі прохолодна. Поруч з водоспадом є зручна галявина, де можна розмістити намети. 3 вершини гори Парашки Вашому погляду відкриються чудові навколишні краєвиди. Звідси можна побачити долини річок Стрий та Великої Річки, села Верхнє Синьовидне та Корчин. Побачите також і гору Тростян. Завершується маршрут поверненням до міста Сколе.

Велосипедний маршрут "Сколе - Ключ-Скелі Довбуша - Болехів - Стрий" (62 км). Любителям велосипедних мандрівок пропонують велосипедний маршрут, який $є$ доволі складний, бо проходить по місцевостях різної складності: - асфальтове покриття - $50 \%$, грунтові дороги - $28 \%$, стежки - $16 \%$, хащі - $6 \%$. 3 детальним описом еколого-пізнавальних стежок та маршрутів, які діють на території НПП "Сколівські Бескиди", можна ознайомитись на офіційному сайті Національного парку за посиланням: http://skole.org.ua/skolemajdan.html (Skolivski Beskydy, 2019).

Важливим завданням національних природних парків України та НПП "Сколівські Бескиди" зокрема є управління (планування, організація, координація, контроль) рекреаційною (туристичною) діяльністю, зокрема відвідуванням території. Здійснення такої екотуристичної діяльності (організація збуту туристських послуг, турів) на природно-заповідних територіях покладається на спеціалізовані державні і комерційні (а також спільні акціонерні) структури - туристські фірми (PZF-Ukrainy, 2019).

Для розвитку екологічного туризму потрібно керуватися такими засадами: спрямованість до природи і на використанні переважно природних ресурсів; збереження первозданності навколишнього середовища; пріоритетність екологічного утворення, формування відносин рівноправного партнерства 3 природою; збереженість місцевого соціокультурного середовища; економічна ефективність і стійкий розвиток тих районів, де проходять тури.

Основні завдання програми розвитку екотуризму:

- законодавче оформлення здійснюваної в межах територій НПП екотуристичної діяльності;

- впровадження економічного механізму надання платних туристичних послуг, створення на засадах самозабезпечення, самофінансування та самоокупності госпрозрахункових рекреаційних структурних підрозділів НПП;

- забезпечення національних природних парків рекреаційно-туристичною інфраструктурою відповідно до міжнародних стандартів (умови проживання і харчування туристів, транспортні засоби, спостережні вежі тощо);
- розроблення та облаштування науково-пізнавальних туристських маршрутів та еколого-освітніх екскурсійних стежок відповідно до параметрів внутрішнього та зовнішнього пейзажного різноманіття природних ландшафтів (малі архітектурні форми, інформаційно-охоронні знаки, інформаційні щити тощо);

- обгрунтування і механізм визначення допустимих величин рекреаційних навантажень па ландшафтні комплекси природно-заповідних територій, використовуваних в цілях відпочинку, туризму і лікування;

- інвентаризація та кількісно-якісна оцінка наявних на природно-заповідних територіях рекреаційних природних (бальнеологічні, кліматичні, лісові, пейзажні) та історико-культурних ресурсів;

- формування у туристів, відпочивальників інтелектуально-гуманістичного світобачення та патріотичного ставлення до природної і культурної спадщини країни (Pankiv, \& Bomba, 2016).

Висновки. Отже, рекреаційна діяльність на теритоpiї НПП "Сколівські Бескиди" є прямою інвестицією в економічний розвиток регіону. Вона здійснюється шляхом створення сприятливих умов для відпочинку відвідувачів і охоплює: облаштування екологічних та туристичних маршрутів і зон відпочинку; організацію екологічних таборів для школярів та молоді; залучення місцевого населення до рекреаційної діяльності (надання платних послуг відвідувачам щодо розміщення, харчування та супроводу); надання інформаційних послуг через випуск друкованої, фото- та відеопродукції, виготовлення інформаційних стендів; залучення та співпраця з рекреаційними закладами регіону щодо відвідування території НПП.

Загалом розвиток екологічного туризму у регіоні сприятиме: вирішенню соціально-економічних проблем населення; зменшенню рівня безробіття на селі та розширенню кола зайнятості сільського населення, особливо молоді; розширенню можливостей реалізації продукції особистого підсобного господарства, зокрема, реалізації іiі на місці; покращанню благоустрою сільських садиб, вулиць, загалом сіл; розвитку соціальної інфраструктури; відродженню, збереженню і розвитку місцевих народних промислів, пам'яток історикокультурної спадщини; підвищенню культурно-освітнього рівня сільського населення (LODA, 2019).

Саме НПП створюють унікальну можливість узгодження завдань охорони природи 3 потребами збалансованого використання природних ресурсів та відпочинком населення. НПП $є$ каталізатором сталого розвитку регіону та базою для розвитку рекреаційної, туристичної, еколого-освітньої, природоохоронної, наукової діяльності, стимулом для розвитку супутніх видів підприємницької діяльності в районі. Парк сприяє екологізації різних напрямків господарської діяльності, що здійснюються на його території (лісове, водне і мисливське господарство).

Раціональне освоєння потенціалу національних природних парків, а також регіональних ландшафтних парків забезпечить притік фінансових засобів, зайнятість населення у рекреаційній сфері, розширення сфери оздоровлення населення міст області. Отже, Сколівщина багата на рекреаційно-туристичні ресурси, тому туристичну привабливість регіону неможливо залишити поза увагою, коли йдеться про розвиток екологічного туризму Львівської обл. 


\section{Перелік використаних джерел}

Ekolohichnyi turyzm. (2019). Departament ekolohii ta pryrodnykh resursiv Kyivskoi oblasnoi derzhavnoi administratsii. Retrieved from: http://eko.koda.gov.ua/ekologichnyj-turyzm/. [In Ukrainian].

Kadnichanska, M. (2008). Osoblyvosti rozvytku ekoturyzmu u natsionalnykh pryrodnykh parkakh Lvivshchyny. (Ser. International relations). Bulletin of Lviv University, 24, 101-105. [In Ukrainian].

LODA. (2019). Pryrodno-zapovidnyi fond (Departament ekolohii ta pryrodnykh resursiv LODA). Retrieved from: http://ekologia.lviv.ua/diialnist-departamentu/zberezhenniabioriznomanittia/pryrodno-zapovidnyi-fond). [In Ukrainian].

Pankiv, N. Ye. (2017). Rekreatsiino-turystychni resursy pryrodno-zapovidnoho fondu Ukrainy ta yikh zberezhennia. Stratehiia investytsiino-innovatsiinoho rozvytku ekonomiky Ukrainy $v$ umovakh hlobalizatsii: stan ta shliakhy stanovlennia: Materials of the International scientific and practical conference, Lviv, March 23, 2017 (pp. 214-224). Lviv: Lvivskyi instytut ekonomiky i turyzmu. [In Ukrainian].

Pankiv, N. Ye., \& Bomba, M. Ya. (2016). Ekolohiia z osnovamy ekolohichnoho turyzmu. Lviv: LIET, 318 p. [In Ukrainian].

PZF. (1999). Pryrodno-zapovidnyi fond Ukrainy zahalnoderzhavnoho znachennia. Kyiv: Omeha-L, 240 p. [In Ukrainian].

PZF-Ukrainy. (2019). Terytorii ta obiekty PZF Ukrainy. Retrieved from: http://pzf.menr.gov.ua. [In Ukrainian].

Skolivski Beskydy. (2019). Ofitsiinyi sait Natsionalnoho pryrodnoho parku. Retrieved from: http://skole.org.ua/rekreatsijni-zony-naterytoriji-npp-skolivski-beskydy.html. [In Ukrainian].

Ukaz Prezydenta Ukrainy. (1999). Pro stvorennia natsionalnoho pryrodnoho parku "Skolivski Beskydy" vid 01.02.1999 r., № 157/99. [In Ukrainian].

Vorobiova, O. A., \& Kharichkov, S. K. (2009). Rozvytok rekreatsiinoturystychnoi diialnosti na terytoriiakh pryrodno-zapovidnoho fondu Ukrainy. Odessa: IPREED NANU, 36 p. [In Ukrainian].

\section{N. E. Pankiv}

Lviv Polytechnic National University, Lviv, Ukraine

\section{PROTECTED AREAS AS A BASE FOR THE DEVELOPMENT OF ECOLOGICAL TOURISM IN LVIV REGION ON THE EXAMPLE OF SKOLEVSKY BESKYDY NATIONAL NATURE PARK}

The existing objects of the nature reserve fund of the Lviv Region, which have important recreational tourism significance, are analyzed. It is revealed that national nature parks, which actively develop ecological tourism, are the most important for the recreational and tourism sphere. The peculiarities of development of ecological tourism in national nature parks are analysed. It is found that the most widespread type of ecological tourism in the protected areas is the walking ecological trails. The recreational and tourism resources of Skolevski Beskydy National Nature Park are considered for their conservation and rational use. In particular, the ecological-cognitive trails and routes are as follows: Skole town- Parashka Mount-Maidan village; Buchyna; Lopata; Vodospad; Nyzhnie Synovydnie - Trukhaniv - Kliuch Mountain - Skole, and cycling route Skole - Kliuch - Skeli Dovbusha - Bolechiv Stryi. We have defined that promising for recreational use is the valley of the Great River, Tustan Fortress (Pidgorodovtsevsky Forestry), the valley of the Kam'yanka River (Dubinske Forestry), the tract of Pavlov Potyk, Zelemianka (Skole Forestry), Skole town, the tract of Panasivka (Korostiv Forestry). The problems and perspectives of use of recreational and tourist resources of Skole region for ecotourism are covered. An important task of Lviv national nature parks and Skolivsky Beskydy NNP, in particular, is the management (planning, organization, coordination, control) of recreational (tourism) activities, in particular visiting the territory. It is also established that these are the national nature parks that create a unique opportunity to reconcile nature conservation tasks with the needs of balanced use of natural resources and recreation of the population. National nature parks are a catalyst for the sustainable development of the region and a base for the development of recreational, tourism, environmental education, environmental protection, scientific activities, and an incentive for the development of related types of entrepreneurial activity in the area. The park promotes ecologization of various areas of economic activity carried out on its territory (forest, water and hunting).

Keywords: recreational and tourism resources; nature reserve fund; national nature parks; Skolevski Beskydy NNP; ecological tourism. 